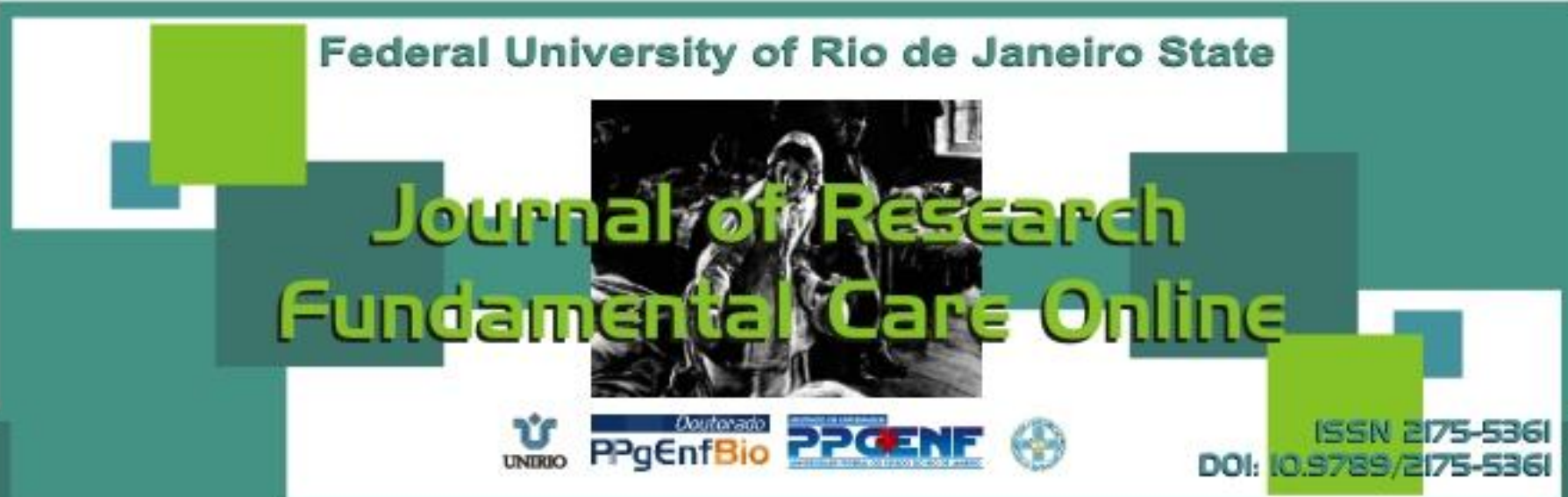

\title{
REVIEW INTEGRATIVE
}

\section{Segurança do paciente: como a enfermagem vem contribuindo para a questão?}

Patient safety: how nursing is contributing to the issue?

¿Seguridad del paciente: cómo la enfermería viene contribuiendo a la cuestión?

Flávia Danyelle Oliveira Nunes ${ }^{1}$, Lidiane Andréia Assunção Barros ${ }^{2}$, Roseane Mafra Azevedo ${ }^{3}$, Sirliane de Souza Paiva ${ }^{4}$

\section{ABSTRACT}

Objectives: Characterizing the scientific production in nursing journals on patient safety and identifying the contributions of these productions for the same. Method: Integrative review in the databases of the Virtual Library of Nursing using the following health descriptors: nursing, patient safety, iatrogenic disease and adverse events. Results: We identified 6 categories: Culture of patient safety, adverse events, nursing care, education, reporting and ethical aspects. Conclusion: therefore, we checked the focal point of the researches, their contributions and advancements needed. Descriptors: Nursing, Patient safety, latrogenic disease, Medical errors.

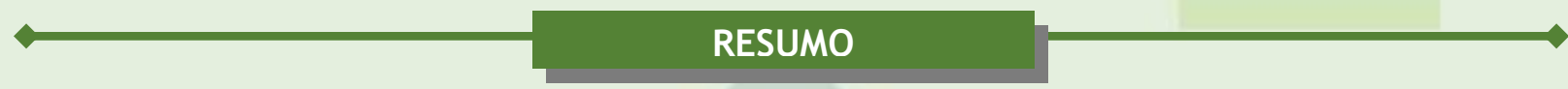

Objetivos: Caracterizar as producões científicas em periódicos de enfermagem sobre segurança do paciente e identificar as contribuições dessas produções para a mesma. Método: Revisão integrativa nas bases de dados da Biblioteca Virtual de Enfermagem utilizando os descritores em saúde: enfermagem, segurança do paciente, doença iatrogênica e eventos adversos. Resultados: Identificamos 6 categorias: Cultura de segurança do paciente, eventos adversos, Assistência de Enfermagem, educação, notificação e aspectos éticos. Conclusão: Verificamos, assim, os focos das pesquisas, suas contribuições e os avanços necessários. Descritores: Enfermagem, Segurança do paciente, Doença iatrogênica, Erros médicos.

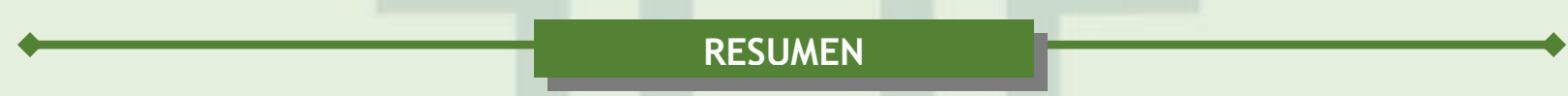

Objetivos: Caracterizar la producción científica en revistas de enfermería a cerca de la seguridad del paciente e identificar las contribuciones de estas producciones para el mismo. Método: revisión Integral en las bases de datos de la Biblioteca Virtual de Enfermería utilizando los descriptores en la salud: enfermería, seguridad del paciente, las enfermedades iatrogénicas y los eventos adversos. Resultados: identificamos 6 categorías: Cultura de la seguridad del paciente, los efectos adversos, la atención de enfermería, la educación, la información y los aspectos éticos. Conclusión: Tomamos nota, también, de los focos de la investigación, sus aportaciones y avances necesitados. Descriptores: Enfermería, Seguridad del paciente, Las enfermedades iatrogénicas, Los errores médicos.

${ }^{1}$ Nurse. Member of Multidisciplinary Team of Nutritional Therapy of the Municipal Hospital Djalma Marques - Socorrão I, São Luis - Maranhão. Member of the Research Group of Psychomotor Skills for Care (HPPC) of the Federal University of Maranhão UFMA. Specialist in Clinical-Surgical Nursing by UFMA. Master in Nursing from UFMA. Email: enfflaviadanyelle@hotmail.com ${ }^{2}$ Nurse. Assistant of the Intermediate Care Unit of the Children's Hospital "Dr. Odorico Amaral de Mattos", São Luís - MA. Member of the Research Group HPPC of the Federal University of Maranhão - UFMA. Specialist in Clinical-Surgical Nursing by UFMA. Master's Academic in Nursing UFMA. Email: lidibarros84@hotmail.com ${ }^{3}$ Nurse. Assistant of the Emergency Unit of the Municipal Hospital Djalma Marques - Socorrão I, São Luís - MA. Member of the Research Group HPPC of the Federal University of Maranhão - UFMA. Specialist in Clinical-Surgical Nursing by UFMA. Master's Academic in Nursing UFMA. Email: mafraroseane@bol.com.br ${ }^{4}$ Nurse. Professor of Nursing at the Federal University of Maranhão - UFMA, São Luís - MA. Group Leader of the Research Group HPPC of UFMA. Post-Doctorate in Nursing from the College of Nursing, University of São Paulo EEUSP. Email: paivasirliane@uol.com.br. 


\section{INTRODUCTION}

atient's safety sets "to reduce the risk of unnecessary harm associated with healthcare to an acceptable minimum". 1:22 These damages, currently called adverse events (AEs) are unintended injuries or complications arising from care provided to patient, which can cause injury or disability, temporary or permanent, prolongation of hospitalization and even death, having no correlation with disease that determined admission. $^{2-3}$

It is a matter of concern remote, but who rose to prominence in 1999 with the publication of the report To Err is Human: building a safer health system by the Institute of Medicine of the United States. At that time, it was found that about 44.000 to 98.000 people died each year in that country, due to AEs, mostly preventable. ${ }^{4}$ From this publication originated the movement in favor of patient safety, among them stands the World Alliance for Patient Safety linked to WHO.

The worldwide incidence of AEs is high. Studies in the United States, Australia, UK, New Zealand, Canada, the Netherlands and Sweden found that 2,9 to $16,6 \%$ of hospitalized patients were victims of AEs, $50 \%$ preventable. We also observed that most caused mild disability but emphasize by 4,9 to $13,6 \%$ of these events led to patient death. In Brazil, a study conducted in the emergency department of a university hospital showed that $50 \%$ of patients at hospital discharge and $70 \%$ of who died experienced at least one AE. Already on research conducted in three teaching hospitals in Rio de Janeiro in 2009, the incidence of patients suffering from these AEs was $7.6 \%, 66,7 \%$ were preventable. ${ }^{3,5-6}$

The surveys confirm the magnitude of the issue. Consequences arising from the breach of patient safety increase spending on health and hospitalization time, causing complications and deaths, which results in the reduction of user trust in the healthcare system and results in psychological damage.

Among health professionals, nursing staff is the most likely to commit AEs since performs several invasive interventions and stays for a long time with the patient.

Given the premise, we question: What is the scientific production of nursing on patient safety, and how this has contributed to the quality of care?

Thus, the study aimed to characterize the scientific production published in nursing journals about patient safety, and to identify the contributions of these to the quality of care.

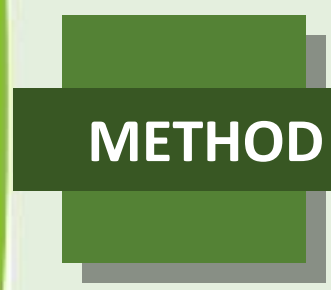

This is an integrative review conducted in the databases of the Virtual Library of Nursing using the descriptor Health (DESCs) "nursing" associated with descriptors: patient 
safety, iatrogenic disease and AEs in Portuguese, English and Spanish. The AEs descriptor is not cataloged in DESCs, but is the International Classification for Patient Safety of the WHO.

Publications with full articles, published in nursing journals since 2004, year of establishment of the World Alliance for Patient Safety/WHO have been selected.

In the initial screening of title and abstract readings were performed. Accordingly, we considered the contemplated articles to established goals. Year of publication, journal name, authors of the study, the research site, approach the study sample, objectives, results and conclusions: Following the full text of the articles and book report of the data was performed. The articles were grouped by subject and presented in graphs and tables.

\section{RESULTS AND DISCUSSION}

There were identified in the survey 57 publications, as noted in Table 1. Of these, 36 (63\%) were performed in Brazil, with 27 (47\%) published in national journals. The searches were performed on documents $(22 ; 39 \%)$, as well as professionals, nursing students $(18 ; 32 \%)$ and patients $(07 ; 12 \%)$. As shown in Figure 1 , in 2004 we did not identify any publications.

Table 1 - Characterization of nursing production on patient safety for the period from 2004 to 2012 according to periodical, place of performance and sample.

\begin{tabular}{|c|c|c|}
\hline Results & $\mathbf{N}$ & $\%$ \\
\hline \multicolumn{3}{|l|}{ National Journals } \\
\hline Brazilian Journal of Nursing - REBEn & 06 & 10 \\
\hline Journal of school of nursing of UERJ & 03 & 5 \\
\hline Journal of the nursing school of the University of São Paulo & 06 & 11 \\
\hline Electronic journal of Nursing & 03 & 5 \\
\hline Other national journals & 09 & 16 \\
\hline Total national journals & 27 & 47 \\
\hline \multicolumn{3}{|l|}{ International Journals } \\
\hline Cuban Journal of nursing & 05 & 9 \\
\hline Latin American Journal of nursing & 10 & 18 \\
\hline Resource Nursing Health & 02 & 3 \\
\hline Other international journals & 13 & 23 \\
\hline Total of international journals & 30 & 53 \\
\hline Total of periodicals & 57 & 100 \\
\hline \multicolumn{3}{|l|}{ Place of performance } \\
\hline Belgium & 01 & 2 \\
\hline Brazil & 36 & 63 \\
\hline Brazil and USA & 01 & 2 \\
\hline Canada & 01 & 2 \\
\hline Colombia & 01 & 2 \\
\hline Cuba & 05 & 8 \\
\hline Spain & 01 & 2 \\
\hline USA & 11 & 19 \\
\hline Total & 57 & 100 \\
\hline \multicolumn{3}{|l|}{ Sample } \\
\hline Documents & 22 & 39 \\
\hline Patients & 07 & 12 \\
\hline Professionals and students of nursing & 18 & 32 \\
\hline Other & 10 & 17 \\
\hline Total & 57 & 100 \\
\hline
\end{tabular}




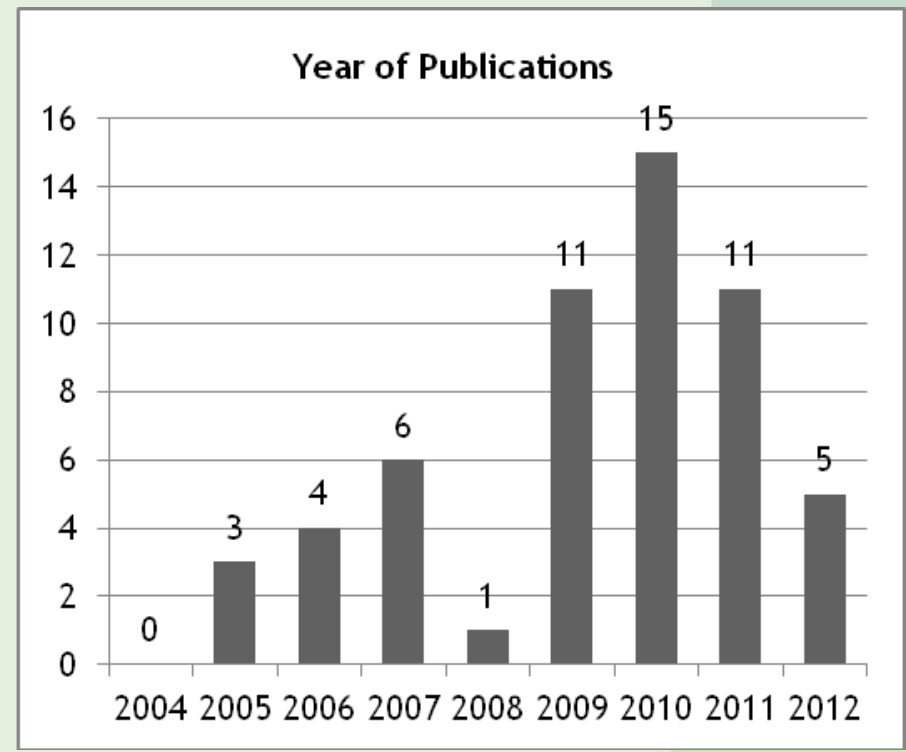

Figure 1 - Distribution of the production of nursing on patient safety, according to the year of publication.

Six themes have been identified, as described in Figure 2:

\begin{tabular}{|c|c|}
\hline THEMES & SUBTHEMES \\
\hline Patient safety culture & $\begin{array}{l}\text { Implementation facilitators - training, continuing education, } \\
\text { professional - patient communication and research; Difficulties of } \\
\text { implementation - corporatism, institutional philosophy, } \\
\text { infrastructure, demand, administrative structure, lack of } \\
\text { evaluation, noise assessment, insecurity, lack of training and } \\
\text { continuing education, lack of partnership with managers, lack of } \\
\text { patient safety commissions, lack of incorporation of Patient Safety } \\
\text { Network; Differences in perceptions - length of service; Need for } \\
\text { scientific basis - practical activities and assistance administration. }\end{array}$ \\
\hline Adverse events & $\begin{array}{l}\text { Identification of AEs - errors during: the administration of } \\
\text { medications, installation of catheters and probes. Falls and } \\
\text { pressure ulcers. }\end{array}$ \\
\hline Nursing care & $\begin{array}{l}\text { Ineffective nursing care - related to occurrence of AEs; Time of } \\
\text { nursing care - related to medication administration errors; Time of } \\
\text { professional experience - related to the incidence of urinary tract } \\
\text { infections; Number of professionals - related to reduction of } \\
\text { mortality in the immediate postoperative period. }\end{array}$ \\
\hline Education & $\begin{array}{l}\text { Vocational training - with caregiver profile, focused on patient } \\
\text { safety; Use of technology - development of virtual specific } \\
\text { environment. }\end{array}$ \\
\hline Notification & $\begin{array}{l}\text { Notification of AEs - performed by nurses, higher incidence in } \\
\text { medication administration; Underreporting of AEs - related to } \\
\text { embarrassment and fear of punishment; Penalties for the pros - } \\
\text { verbal warning; Instruments for notification - need for elaboration. }\end{array}$ \\
\hline Ethical aspects & $\begin{array}{l}\text { Actions of professionals in occurrence of AEs - were based on } \\
\text { values and beliefs, in appreciation of the work and the experiences } \\
\text { that they experienced. }\end{array}$ \\
\hline
\end{tabular}

Figure 2 - Themes identified in the productions of nursing on patient safety, for the period from 2004 to 2012.

The scientific literature on patient safety has grown every year since the creation of the World Alliance for Patient Safety by WHO. We emphasize that in 2008 was identified only one publication, unknown reason for the decrease in production in that year.

We emphasize that Brazil was the leading of scientific production in this area, although inconsistently, because only a small percentage was performed with patients who, in turn, are the subjects that could damage resulting from failures in health care. 
The theme of "adverse events" was the most published corroborating the priority of the political agenda of the WHO member states with patient safety. AEs are unintended harm, and their most preventable, resulting from care provided by health professionals. Such damage can be temporary or permanent physical, psychological or social. ${ }^{7-8}$ They have, however, a major impact on health and global spending and its rate has been used as an indicator of the quality of health services, which explains the large number of publications on this topic.

The main events were related to medications, probes, drains and catheters, falls and pressure ulcers. Activities in which nursing is directly connected, which demands a lot of attention these professionals not only in the prevention, harm reduction to the patient as well as the notification of these events, that "[...] are important sources of alerts and information, promoting safety in the hospital environment and contributing to the management of nursing care". 9:288 But in the world of nursing scientific production, this topic has not highlighted.

We emphasize that there is still a high incidence of underreporting, as well as incomplete reports. In a study conducted in São Paulo in 2007 with intensive care nurses, about 50 to $71,4 \%$ of them showed underreporting of AEs in their work units and indicated as main reasons overwork, forgetfulness, no recovery of such events, fear and shame, and the feeling of fear related to the culture of punishment, still lingering in health facilities. ${ }^{10}$

AEs may result from reversible damage to death. When AEs are related to drug administration is not uncommon to be featured in the media and that these are related to the work of the nursing team.

AEs in medications are preventable events related to drugs under control of professionals or patients, causing damage. A study of nursing technicians found that $62,69 \%$ of medication errors were related to the preparation and, of these, the rate with the potential to alter the microbiological safety was above $70 \%$. 53,68\% of the errors corresponded to the anticipated preparation that may have altered the chemistry of some drugs, thereby modifying the therapeutic outcome. In $6,29 \%$ of cases there were dosing errors. ${ }^{11}$

The above figures indicate the severity of the problem and are indirectly related to various factors such as technical causes, limited human resources, illegible prescriptions, work overload due to high demands and multiple employments.

The falls were also mentioned, but despite the small percentage are events that require care, especially with seniors. In the United States these events were the main cause of accidental death in the elderly. ${ }^{12}$

Regarding the safety culture of the patient is necessary to develop strategies to eliminate or reduce barriers to implementation. Among these provide working conditions for nursing staff, considering the impact the care provided by these professionals in patient safety. It was found that a deficient team of nurses is associated with poor medication errors, falls, and spread of infections, increased mortality and deficit in resuscitation of patients. ${ }^{13}$

We added to appropriate working conditions, the importance of training and update as having one of the goals for patient safety, said member in only $11 \%$ of the articles 
surveyed. Since the quality of students' education is essential to produce professionals capable of working in the development of systems for patient safety. ${ }^{14}$

We consider as essential the approach of patient's safety focused on ethical aspects. According to this research, are still incipient the scientific productions turned to the theme. The ethical occurrences, ie, the faults committed by professionals and that result in harm to patients may be due to negligence - Divergent action of right, arising from passivity or inaction professional - malpractice - lack of knowledge or ability to perform a particular function or recklessness - exposing the patient to unnecessary risks, precipitous action. ${ }^{15}$

\section{CONCLUSION}

Patient's safety is an old question, but specific professional approaches, as well as conducting research are still recent. However, there is a growing profile, which is positive for diagnosis as well as proposing strategies those can positively impact factors related to safety.

The Brazilian Nursing emerged in research on patient safety, contributing to improving the quality of health care services. But few studies have been carried out directly with the patient.

Other topics discussed in regard to patient safety were the AEs, staff training, notifications of events and ethical issues.

The contributions of the studies were diverse, since the evaluation of health services through research of $\mathrm{AEs}$, reflections on nursing performance to propose strategies to promote patient safety.

\section{REFERENCES}

1. World Health Organization. More than words: Conceptual Framework for the International Classification for Patient Safety Version 1.1. [ ]; 2009. 154p.

2. Mendes W, Travassos C, Martins M, Noronha JC. Revisão dos estudos de avaliação da ocorrência de eventos adversos em hospitais. Rev bras epidemiol. 2005; 8(4): 393-406.

3. Zambon LS, Gallotti RMD. Segurança do Paciente: uma nova dimensão como base da qualidade da assistência em saúde. Rev Soc Bras Clín Méd. 2011 nov; 1(2): 1-7.

4. Institute of Medicine. To err is human: building a safer health system. [ ]; 1999. 8p.

5. Gouvêa CSD, Travassos C. Indicadores de Segurança do paciente para hospitais de pacientes agudos: revisão sistemática. Cad saúde pública. 2010 jun; 26(6): 1061-78.

6. Pedreira MLG. Práticas de enfermagem baseadas em evidências para promover a segurança do paciente. Acta paul enferm. 2009; 22(Especial - 70 Anos): 880-1. 
7. Souza LP, Bezerra ALQ, Silva AEBC, Carneiro FS, Paranaguá TTB, Lemos LF. Eventos adversos: instrumento de avaliação do desempenho em centro cirúrgico de um Hospital Universitário. Rev enferm UERJ. 2011 jan/mar; 19(1): 127-33.

8. Carneiro FS, Bezerra ALQ, Silva AEBC, Souza LP, Paranaguá TTB, Branquinho NCSS. Eventos adversos na clínica cirúrgica de um Hospital Universitário: instrumento de avaliação da qualidade. Rev enferm UERJ. $2011 \mathrm{abr} /$ jun; 19(2): 204-11.

9. Paiva MCMS, Paiva SAR, Berti HW. Eventos adversos: análise de um instrumento de notificação utilizado no gerenciamento de enfermagem. Rev Esc Enferm USP. 2010; 44(2): 287-94.

10. Claro CM, Krocockz DVC, Toffolleto MC, Padilha KG. Eventos adversos em Unidade de Terapia Intensiva: percepção dos enfermeiros sobre a cultura não punitiva. Rev Esc Enferm USP. 2011; 45(1): 167-72.

11. Camerini FG, Silva LD. Segurança do paciente: análise do preparo de medicação intravenosa em Hospital da Rede Sentinela. Texto \& contexto enferm, Florianópolis. 2011 jan-mar; 20(1): 41-9.

12. Moreira MD, Costa AR, Felipe LR, Caldas CP. Variáveis associadas à ocorrência de quedas a partir dos diagnósticos de enfermagem em idosos atendidos ambulatorialmente. Rev latinoam enferm. 2007 mar-abr; 15(2): 137-43.

13. Lucero RJ, Lake ET, Aiken LH. Nursing care quality and adverse events in US hospitals. J Clin Nurs. 2010 August; 19(15-16): 2185-95.

14. Sol AA, Vázquez RF. Influencia del desarrollo de la personalidad profesional durante La carrera de Enfermería en la seguridad del paciente. Rev cuba enferm. 2011; 27(1): 8-15.

15. Vargas MAO, Ramos FRS. latrogenias nas unidades de terapia intensiva: dramaticidade dos problemas bio/éticos contemporâneos. Rev latinoam enferm. 2010 set-out; 18(5): tela 1-9. 